\title{
Sayuran Organik Lahan Kering Untuk Pariwisata Di Dompu
}

\author{
A. Farid Hemon', Hanafi Abdurrachman ${ }^{1}$ \\ ${ }^{\text {I}}$ Program Studi Agroekoteknologi Fakultas Pertanian Universitas Mataram, Mataram, NTB, Indonesia
}

\begin{abstract}
Article history
Received: 31 Mei 2021

Revised: 11 Juni 2021

Accepted: 21 Juni 2021

*Corresponding Author: A.

Farid Hemon, Fakultas

Pertanian Universitas Mataram,

Mataram, Indonesia

Email:

faridhemon_1963@yahoo.com
\end{abstract}

Abstract: This science and technology application was carried out to educate partner farmers (1) "Mada Kabuntu Farmer Group" and (2) "Sinar Rinjani Farmer Group" to increase the production of organic vegetables in dry land to tourism supporting Dompu Distric. To achieved this goal, training activities and plot demonstration have been carried out. The training method used was the adult education method with participatory techniques. The training participants were members of the farmers group "Mada Kabuntu" and "Sinar Rinjani". Training activities include explanation of modules (with LCD and props), discussion and question and answer. Plot demonstrations and organic vegetable cultivation practices were carried out on farmers' land. Farmers were participatively involved jointly from planning, implementing and evaluating of harvest yield. The activity results showed that the farmers participating in this program were very responsive to the development of organic vegetables on dry land. The participating farmers were actively working together to carried out all phases of activities from training, demonstration plots from planting, plant maintenance and harvesting. The results of these activities indicated that there has been a technology transfer process for developing organic vegetables in the dry land Dompu district.

Keywords: biological pesticide, organic farming, tourism, compos

Abstrak: Penerapan IPTEKS ini dilakukan untuk membantu mitra (1) "Kelompok Tani Mada Kabuntu" dan mitra (2) "Kelompok Tani Sinar Rinjani" meningkatkan produksi sayuran organik di lahan kering untuk menunjang pariwisata Kabupaten Dompu. Untuk mencapai tujuan tersebut maka telah dilakukan kegiatan pelatihan dan demonstrasi plot. Metode yang digunakan dalam pelatihan adalah metode pendidikan orang dewasa (POD) dengan teknik partisipatif. Peserta pelatihan teknis yaitu pengurus Kelompok Tani dan Anggota Kelompok "Mada Kabuntu" dan "Sinar Rinjani". Kegiatan pelatihan meliputi penjelasan materi (dengan LCD dan alat peraga), diskusi dan tanya jawab. Demonstrasi plot dan praktek budidaya sayuran organik dilakukan di lahan petani. Petani secara partisipatif ikut terlibat secara bersama-sama dari perencanaan, pelaksanaan dan evaluasi hasil panen. Hasil kegiatan menunjukkan bahwa petani peserta sangat respons terhadap kegiatan pengembangan sayuran organik di lahan kering. Petani peserta secara gotong royong aktif melaksanakan semua tahapan kegiatan dari pelatihan, pembuatan demplot, penanaman, pemeliharaan tanaman dan pemanenan. Hasil kegiatan ini menunjukkan bahwa telah terjadi proses transfer teknologi pengembangan sayuran organik di lahan kering kabupaten Dompu.

Kata kunci: kompos, organic farming, pariwisata, pestisida hayati 


\section{PENDAHULUAN}

Kabupaten Dompu termasuk daerah destinasi baru untuk pengembangan wisata di NTB. Hal ini ditandai dengan kegiatan “Tambora Menyapa Dunia” tentang 2 abad letusan gunung Tambora dan Festival Pesona Tambora (FPT) dengan tema The Magical of Tambora 2020. Kunjungan wisata baik wisata domestik dan mancanegara cenderung mengalami peningkatan dari tahun ke tahun. Pada tahun 2020 jumlah kunjungan wisatawan domestik mencapai 95.745 dan mancanegara mencapai 28.267 orang (BPS, 2020). Selain obyek wisata gunung Tambora, wisata bahari berupa olah raga selancar angin di pantai "Lakey" juga merupakan kegiatan yang sangat digemari oleh wisatawan macanegara.

Kepariwisataan dikembangkan untuk mendorong peningkatan daya saing perekonomian nasional, peningkatan kualitas perekonomian, dan kesejahteraan masyarakat lokal, serta perluasan kesempatan kerja. Pengembangan kepariwisataan dapat dilakukan dengan memanfaatkan secara arif dan berkelanjutan keragaman pesona keindahan alam dan potensi wilayah bahari terluas di dunia serta dapat mendorong kegiatan ekonomi yang terkait dengan pengembangan budaya bangsa (Rencana Pembangunan Jangka Panjang Dompu, 2005-2025).

Kabupaten Dompu secara geografis mempunyai luas 2.324, $55 \mathrm{Km}^{2}$ dengan dominasi lahan kering dan beriklim kering dengan intensitas rata-rata curah hujan $122 \mathrm{~mm}$ per bulan serta jenis tanah didominasi oleh jenis Litosol kompleks, Entisol, Vertisol, dan Aluvial. Jumlah penduduk hanya sekitar 306.126 orang, dengan mata percaharian utama adalah pertanian tanaman pangan. Tingkat kemiskinan masih menghantui kabupaten Dompu $(19,9 \%)$, walaupun dari tahun ketahun cenderung mengalami penurunan seiring dengan pengembangan progran PIJAR (sapi, jagung dan rumput laut) dan pengembangan pariwisata.

Kabupaten Dompu sebagai daerah destinasi baru pengembangan wisata, maka diperlukan pengembangan sub sektor lain seperti pembangunan pertanian. Sektor pertanian memiliki posisi yang sangat strategis untuk menopang pembangunan daerah menuju masyarakat yang sejahtera. Potensi usaha telah terbukti mampu mengatasi persoalan kelaparan, kemajuan ekonomi daerah, dan penyerapan tenaga kerja. Penciptaan swasembada pangan dan kedaulatan pangan harus direncanakan terutama untuk mencapai kesejahteraan masyarakat. Di sisi lain, sektor pertanian termasuk di dalamnya subsektor tanaman pangan dan hortikultura merupakan pemasok bahan kebutuhan pangan dan bahan baku industri berharga murah. Subsektor tanaman pangan dan hortikultura merupakan tumpuan bagi sebagian besar penduduk terutama dalam upaya menghapus kemiskinan dan meningkatkan kesejahteraan ekonomi.

Pengembangan pertanian terutama penyediaan komoditas sayuran menjadi kebijakan utama untuk meningkatkan ketersediaan per kapita hortikultura yang mengacu pada rekomendasi konsumsi per kapita dari FAO, yaitu sayuran dan buah-buahan masing-masing sebesar $65 \mathrm{~kg} / \mathrm{kapita} / \mathrm{tahun}$ serta untuk menghasilkan produk sayuran dengan jumlah dan mutu sesuai permintaan pasar (Rasahan, 1999).

Kebutuhan sayuran cenderung meningkat dari tahun ke tahun sesuai dengan permintaan pasar akan kebutuhan restoran dan hotel. Hasil survei awal bahwa kebutuhan sayuran untuk restoran dan hotel sebagian besar 
berasal dari pulau Lombok dan Bali. Oleh karena itu, kegiatan ini diharapkan petani mampu menghasilkan sayuran organik yang bermutu.

Petani sebenarnya telah terbiasa menanam sayuran. Petani di sini menanam sayuran secara turun temurun, dan belum banyak mengenal jenis sayuran yang berkualitas tinggi dan sayuran yang dikonsumsi oleh turis mancanegara. Selama ini petani hanya menanam sayuran jenis lokal, tidak berkualias dan belum menerapkan input teknologi yang bebas bahan kimia. Produk sayuran bebas bahan kimia merupakan syarat untuk menghasilkan sayur organik. Produk sayuran organik menjadi trend di masa sekarang karena mampu menghasilkan sayuran yang sehat dan bergizi.

Pertanian organik adalah sistem budidaya pertanian yang mengandalkan bahan-bahan alami tanpa menggunakan bahan kimia sintetik (Balai Penelitian dan Pengembangan Pertanian, 2002). Beberapa tanaman yang berpotensi untuk dikembangkan dengan teknik tersebut adalah sayuran (seperti petsai, kubis merah, cabe, jagung manis). Pengolahan pertanian organik didasarkan pada prinsip kesehatan, ekologi, keadilan, dan perlindungan. Untuk mencapai pertanian organik yang baik perlu dilakukan pengelolaan yang berhati-hati dan bertanggungjawab melindungi kesehatan dan kesejahteraan manusia.

Sebagian besar petani menanam sayuran pada awal musim kemarau atau akhir musim hujan. Kondisi lahan kering dan kesulitan sumber pengairan menyebabkan hasil panen sedikit dan kualitas sayuran tidak tidak baik dan tidak memenuhi standar pasar. Selain itu, masalah harga menjadi hal yang sangat memukul perasaan petani karena ketika masa panen, harga sayuran sangat rendah dan petani hanya pasrah. Permasalahan yang dihadapi ini menyebabkan pendapatan petani sayuran menjadi rendah. Kondisi ini yang menjadi alasan untuk melaksanakan kegiatan aplikasi Iptek untuk membantu petani dalam hal manajemen produksi dan pemasaran, dan penguatan kelembagaan.

Beberapa kendala teknis, penyebab rendahnya produktivitas sayuran, yaitu pengolahan tanah untuk penanaman masih jarang dilakukan, umumnya olah tanah minimum atau tanpa olah tanah sehingga tanah menjadi keras atau padat. Rendahnya bahan organik tanah juga ikut mempengaruhi kualitas tanah. Adanya masa kekeringan selama penanaman menyebabkan pertumbuhan sayuran akan terhambat, petani belum menggunakan benih bermutu, serta penanaman varietas lokal dengan produktivitas rendah merupakan masalah dalam budidaya sayuran. Teknik bercocok tanam masih dilakukan dengan cara yang sederhana dengan tanpa pengaturan jarak tanam, tanpa pemangkasan, tanpa pembumbunan, dan tanpa penyiangan. Selama penanaman tidak dilakukan pengendalian hama dan penyakit, karena kondisi ekonomi petani yang terbatas.

Masalah lain dalam pengembangan sayuran di lahan kering adalah harus ada jaminan bahwa sayuran tidak diaplikasikannya pestisida dan pupuk kimia yang berlebihan. Penggunaan pestisida diarahkan untuk menurunkan populasi hama, penyakit atau gulma. Penggunaan pestisida yang berlebihan dapat menimbulkan residu pada sayuran dan berakibat akan merusak kesehatan manusia. Akumulasi dari pestisida di lingkungan dapat mencemari lahan pertanian dan apabila masuk dalam rantai makanan maka dapat menimbulkan macam-macam penyakit, misalnya keracunan, kanker, dan lain-lain (Sofia, 2002). 
Berdasarkan uraian di atas, maka kegiatan ini bertujuan untuk membantu mitra (1) "Kelompok Tani Mada Kabuntu” dan mitra (2) "Kelompok Tani Sinar Rinjani” untuk meningkatkan produksi sayuran organik di lahan kering untuk pariwisata Kabupaten Dompu.

\section{METODE}

Pemecahan masalah yang telah dilakukan pada program ini adalah melalui "Penerapan teknologi budidaya sayuran organik untuk meningkatkan produksi sayuran di lahan kering dan menjadikan Kelompok Tani "Mada Kabuntu” desa Mbawi dan Kelompok Tani "Sinar Rinjani” desa Nusa Jaya sebagai Kelompok Tani andalan yang berorientasi agribisnis sayuran.

Untuk meningkatkan produksi sayuran diperlukan penerapan ilmu dan teknologi yang dimiliki oleh Tim Pengusul berupa kegiatan pelatihan dan demonstrasi plot. Kegiatan yang dilaksanakan meliputi:

\section{Pelatihan}

Metode yang digunakan dalam pelatihan adalah metode pendidikan orang dewasa (POD) dengan teknik partisipatif. Peserta pelatihan teknis yaitu pengurus Kelompok Tani dan Anggota Kelompok "Mada Kabuntu" dan "Sinar Rinjani”. Kegiatan pelatihan meliputi penyampaian modul, penjelasan materi (dengan LCD dan alat peraga), diskusi dan tanya jawab. Materi pelatihan meliputi 1) kebijakan dan prospek usaha tani sayuran di NTB, 2) teknik budidaya sayuran organik (jenis/varietas unggul, benih unggul, pengolahan tanah, penanaman (jarak tanam), pemupukan, pembunbunan dan pengendalian hama/penyakit), 3) Pemanenan, packaging, dan pelabelan, dan 4) Agribisnis sayuran.

\section{Demonstrasi plot}

Setelah melakukan pelatihan teknis secara teoritis, kelompok tani diberikan praktek tentang budidaya sayuran organik. Demonstrasi plot dan praktek produksi sayuran dilakukan di lahan petani seluas 25 are. Petani secara partisipatif ikut terlibat secara bersama-sama dari perencanaan, pelaksanaan dan evaluasi hasil panen.

Tim pengabdian telah memberikan pelayanan teknis kepada petani dengan mengundang partisipatif petani mulai dari penyusunan/perencanaan program, pelaksanaan kegiatan (menanam, memelihara, panen), membandingkan, dan memutuskan apakah program yang dilaksanakan memberi keuntungan atau tidak.

Kegiatan ini diawali dengan menanam berbagai jenis dan varietas unggul sayuran pada bedengan-bedengan dengan ukuran 4 x 20 m. Benih sayuran ditanam secara organik tidak menggunakan pupuk dan pestisida kimia. 


\section{HASIL DAN PEMBAHASAN}

Pada kegiatan ini telah dilalukan beberapa tahapan kegiatan, yaitu pelatihan dan demonstrasi plot (demplot). Pelatihan di sini dilakukan untuk menyampaikan materi penyuluhan yang sesuai dengan topik kegiatan. Agar suatu hasil penelitian mencapai keberhasilan dalam proses adopsinya maka suatu teknologi perlu diperdengarkan, diperlihatkan, dan dilakukan, sehingga dalam pelaksanaan pelatihan perlu dilanjutkan dengan kegiatan praktek berupa demplot.

\section{Pelatihan}

Pelatihan merupakan salah satu bentuk media komunikasi dalam usaha pengembangan informasi pada kegiatan diseminasi hasil-hasil penelitian (Indraningsih, 2011). Hasil penelitian dan pengkajian dari peneliti harus dapat dimanfaatkan oleh pengguna akhir (masyarakat tani/pelaku agribisnis lainnya) dan pengguna antara, sehingga mekanisme dan metode yang tepat harus dilakukan. Kegiatan pelatihan merupakan salah satu metode pendekatan kelompok yang digunakan untuk dapat memberikan informasi yang lebih terperinci tentang sesuatu teknologi, sehingga kegiatan pelatihan dapat membantu seseorang dari tahap menginginkan ke tahap mencoba atau bahkan ketahap menerapkan. Untuk mencapai keberhasilan dalam proses adopsinya, maka suatu teknologi perlu diperdengarkan, diperlihatkan, dan dilakukan, sehingga dalam pelaksanaan pelatihan selain pemberian informasi dalam bentuk ceramah/diskusi perlu dilanjutkan dengan kegiatan praktek.

Metode yang digunakan dalam pelatihan adalah metode pendidikan orang dewasa (POD) dengan teknik partisipatif. Peserta pelatihan teknis yaitu pengurus Kelompok Tani dan Anggota Kelompok Tani. Kegiatan telah dilakukan di sekitar areal demplot penanaman sayuran. Tim telah menjelaskan beberapa topik terutama yang berkaitan dengan pengembangan sayuran organik di lahan kering.

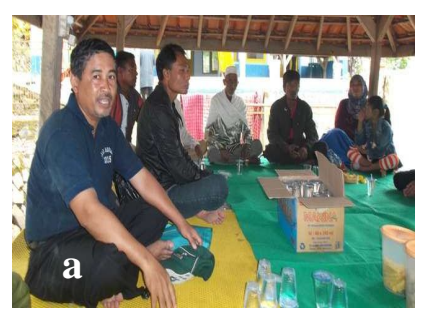

a

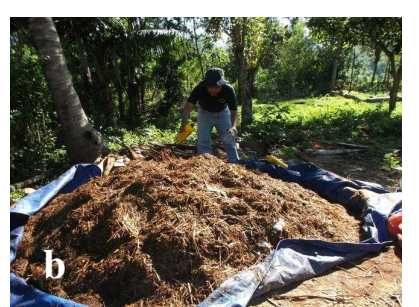

Gambar 1.

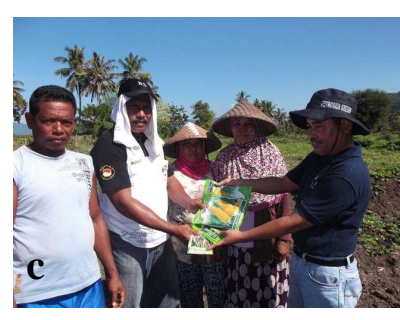

Penjelasan secara teoritis dan praktek lapangan tentang pengembangan sayuran organik. (a) Penyampaian meteri pelatihan,

(b) Penjelasan tentang praktek pembuatan kompos, dan (c) Penjelasan tentang penggunaan benih unggul sayuran dan pembagian benih kepada mitra.

\section{Demonstrasi Plot}

Adopsi teknologi produksi benih tidak hanya cukup dilakukan melalui ceramah atau disikusi, namun perlu dilakukan melalui praktek langsung (Slamet, 2003). Demontrasi plot adalah salah bentuk media penyuluhan yang 
dilakukan melalui praktek langsung dilapangan dengan membandingkan cara petani dan penerapan teknologi produksi sayuran organik.

Demonstrasi plot ini dilakukan berkaitan dengan teknik penanaman sayuran organik di lahan kering dengan menerapkan kompos dan benih bermutu untuk meningkatkan produksi sayur di lahan kering petani. Petani secara partisipatif ikut terlibat secara bersama-sama dari perencanaan, pelaksanaan dan evaluasi hasil panen.

Setelah dilaksanakan pelatihan, maka dilanjutkan dengan penjelasan tentang Demplot. Penjelasan selanjutnya meliputi tentang pembuatan kompos, pembuatan pestisida nabati, pengolahan tanah, pembuatan plot, penerapan budidaya sayur organik, penanaman, pemeliharaan tanaman, dan pemanenan. Pengolahan tanah telah dilakukan satu kali. Setelah diolah dilakukan pembuatan plot. Plot percobaan berukuran 4 x $20 \mathrm{~m}$. Jenis sayuran yang dikembangkan adalah jagung manis, petsai, cabai, terong, pare, dan bayam cabut.

Sebelum penanaman dilakukan pembuatan kompos dengam menggunakan bahan jerami padi, ampas gergaji, rumput-rumput kering, kotoran sapi, dan ditambah EM4 (produk mikroorganisme) untuk mempercepat proses fermentasi bahan organik.

Lokasi demplot dilakukan pada lahan petani dengan kondisi tanah lahan kering dengan iklim kering. Pengolahan tanah dilakukan dengan dipacul oleh anggota kelompok tani yang sebelumnya telah diairi dari sumur dengan cara menaikkan air dengan mesin air. Pengolahan tanah bersamaan dengan penaburan kompos. Penanaman dilakukan sesuai dengan jenis sayuran yang diusahakan.
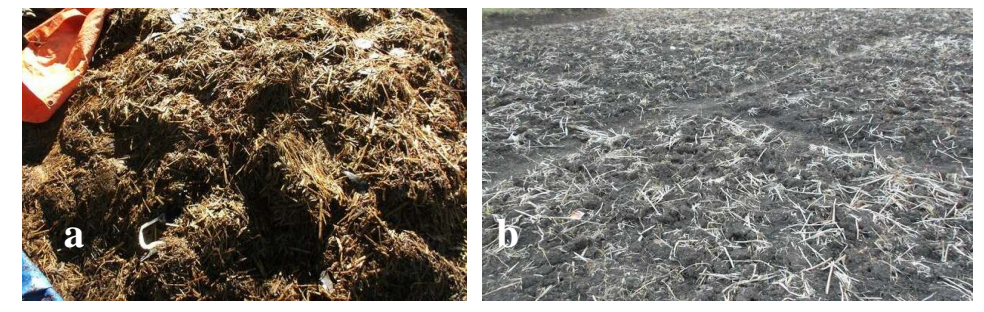

Gambar 2.

Persiapan lahan untuk penanaman.(a) kompos yang siap untuk digunakan, (b) plot percobaan yang sudah ditaburi dengan kompos,
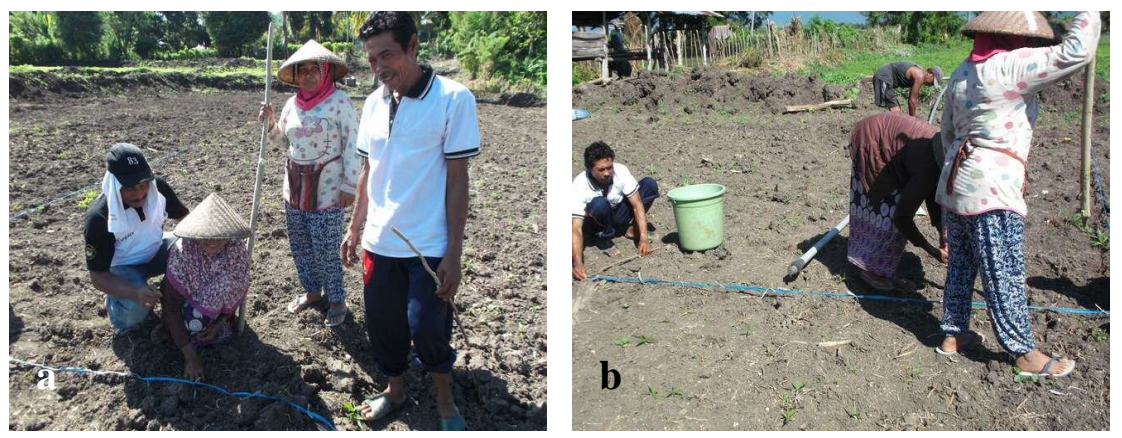

Gambar 3.

Penanaman tanaman seperti jagung manis, bayam, sawi, kacang panjang, cabe, pare, terong, dan sawi 
Penggunaan pupuk kompos pada lahan kering berpengaruh nyata terhadap pertumbuhan tanaman (pengamatan fisual). Tanaman tumbuh subur dengan menghasilkan daun yang luas, jumlah daun yang lebih banyak, tanaman lebih tinggi, warna daun lebih hijau dibandingkan dengan tanaman tanpa penggunaan kompos. Pengamatan hama juga dilakukan, ternyata tanaman ini sangat minim diserang oleh hama atau penyakit.
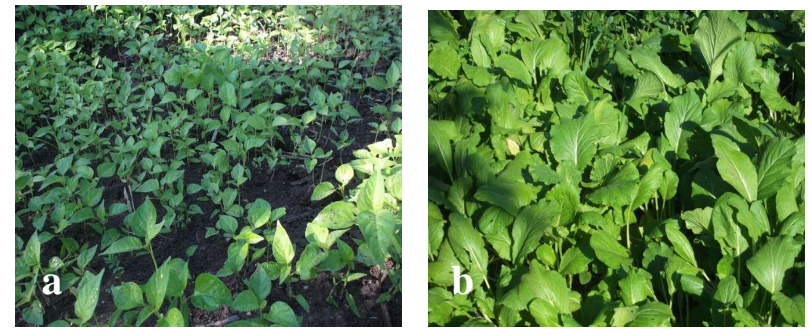

Gambar 4.

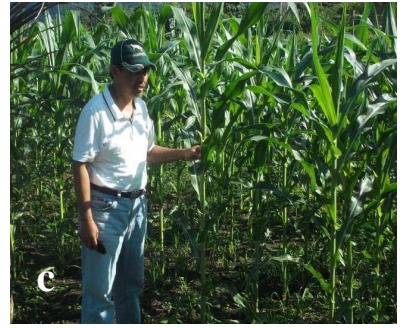

Pertumbuhan tanaman sayuran. (a) Pertumbuhan bibit cabai dalam persemaian, (b) tanaman sawi umur 20 hari, dan (c) pertumbuhan jagung manis umur 45 hari

Pada saat tanaman siap panen, Tim Pengabdian mengundang kembali beberapa peserta kelompok tani dan penyuluh senior serta pegawai Dinas Pertanian tanaman Pangan kabupaten Dompu untuk menyaksikan pemanenan tanaman sayur. Selain kegiatan pemanenan sayuran, maka kegiatan promosi produk sayuran organik dilakukan juga pada salah satu rumah makan yang ada di Kabupaten Dompu, yaitu "Mantika Dompu". Rumah makan ini siap menerima hasil panen sayuran untuk keperluan restoran. Antusias peserta sangat tinggi untuk mengetahui hasil panen (Gambar 5).
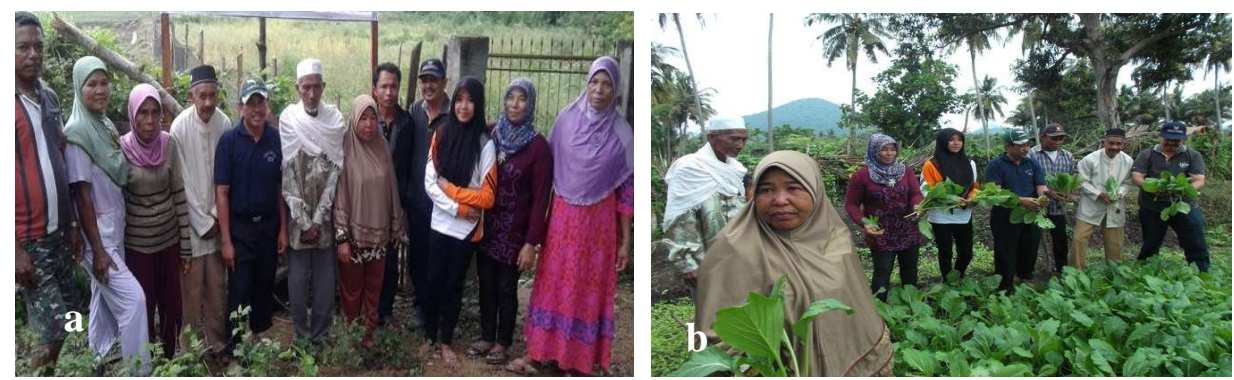

Gambar 5.

Pemanenan tanaman sayuran. (a) Berpose dengan peserta mitra, (b) Panen sayuran bersama mitra

Selama dalam pelaksanaan kegiatan pengabdian, terdapat beberapa faktor pendorong dan faktor penghambat. Faktor pendorong ini merupakan suatu kondisi yang menyebabkan pelaksanaan kegiatan berjalan lancar sehingga tercapai tujuan kegiatan. Faktor-faktor pendorong tersebut adalah:

1. Antusias peserta terhadap pelatihan. Masyarakat memperlihatkan rasa keingintahuannya dengan mengajukan beberapa pertanyaan terhadap penjelasan yang disampaikan oleh Tim. Di samping itu para peserta menunjukkan keseriusan yang tinggi yang dicirikan dengan ketekunan untuk mengikuti pelatihan dari awal hingga akhir kegiatan. Kegiatan ini bukan hanya dilakukan secara ceramah, namun lebih banyak dilakukan dengan praktek di lapangan dan dilakukan secara partisipatif. 
2. Antusias petani terhadap pelaksanaan demplot. Kegiatan ini bertujuan untuk mengajak petani terlibat langsung dalam pengembangan sayuran organik di lapangan. Petani sangat antosias juga mengikuti semua tahapan kegiatan dan memperlihatkan rasa keingintahuannya dengan mengajukan beberapa pertanyaan terhadap kondisi tanaman sayuran di lapangan.

3. Beberapa penjelasan yang disampaikan, mereka memahami. Terbukti dari apa yang telah disuruh dalam kegiatan pembuatan demplot, pembuatan kompos, budidaya tanaman sayuran, pembumbunan, pengamatan gejala hama, pengendalian hama dan penyakit dan pengamatan parameter, mereka telah melaksanakannya dengan baik.

4. Keterlibatan peserta perempuan mendorong semangat peserta laki-laki untuk serius melaksanakan kegiatan demplot. Bahkan anak-anak ikut langsung melaksanakan panen sayuran.

Selain faktor pendorong dalam pelaksanaan kegiatan, terdapat juga faktor penghambat yang merupakan suatu kondisi (lingkungan atau alam) yang menyebabkan pelaksanaan kegiatan menjadi terhambat. Faktor penghambat tersebut adalah:

1. Cuaca ekstrim. Awal penanaman tanamam, curah hujan sangat tinggi sehingga kesulitan untuk menugal benih dan sempat melakukan penyulaman tanaman. Berselang beberapa hari, cuaca sangat kering dan panas sehingga menggangu pertumbuhan tanaman.

2. Pertumbuhan tanaman mendapat gangguan ternak liar. Beberapa tanaman jagung manis pada umur 30 hari dimakan oleh ternak sapi. Kebiasaan petani bahwa sapi dilepas di alam sehingga walaupun dipagari keliling tanaman mendapat ancaman dari sapi yang berkeliaran.

\section{KESIMPULAN DAN SARAN}

Hasil kegiatan menunjukkan bahwa petani peserta program pengabdian sangat respon terhadap kegiatan pengembangan sayuran organik di lahan kering. Petani peserta secara gotong royong aktif melaksanakan semua tahapan kegiatan dari pelatihan, pembuatan demplot dan penanaman, dan pemeliharaan tanaman. Hasil kegiatan ini menunjukkan bahwa telah terjadi proses transfer teknologi pengembangan sayuran organik di lahan kering untuk menunjang pariwisata kabupaten Dompu.

Pengembangan sayuran organik sebaiknya dilakukan di lahan kering melalui penyediaan sumur pompa yang dilakukan secara berkelompok dalam kelompok tani.

\section{Ucapan Terima Kasih}

Tim menyampaikan ucapan terima kasih kepada Direktorat Penelitian dan Pengabdian Kepada Masyarakat Direktorat Jenderal Pendidikan Tinggi Kementerian Riset, Teknologi, dan Pendidikan Tinggi atas dukungan dana dan penugasan untuk melaksanakan kegiatan pengabdian masyarakat. 


\section{Daftar Pustaka}

Balai Penelitian dan Pengembangan Pertanian, 2002. Prospek Pertanian Organik di Indonesia. Diakses 23 Mei 2010.

Indraningsih, K.S., 2011. Pengaruh Penyuluhan terhadap Keputusan Petani dalam Adopsi Inovasi Teknologi Usahatani. Jurnal Agro Ekonomi 29(1): 1-24.

Rasahan C.A., 1999. Arah Kebijaksanaan Pembangunan Tanaman Pangan dan Hortikultura. Direktur Jenderal Tanaman Pangan dan Hortikultura. Jakarta.

Slamet, M. 2003. Pemberdayaan Masyarakat, dalam Membentuk Pola Perilaku Manusia Pembangunan. Penyunting: Ida Yustina dan Ajat Sudrajat, 45 - 48. IPB-Bogor.

Soetanto, R. 2002. Penerapan Pertanian Organik Pemasyarakatan dan Pengembangannya. Kanisius. Yogyakarta. 219 hal.

Sofia D., 2002. Pengaruh Pestisida dalam Lingkungan Pertanian. USU Sumatera Utara. 